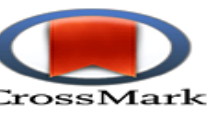

\title{
Ecological Communication
}

\section{Role of Socio-Geographical Parameters in Natural Resource Management of Belgorod Region, Russia}

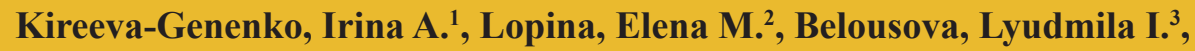 \\ Mitryaykina, Antonina $\mathbf{M}^{4}$ and Martsinevskaya, Larisa $\mathbf{V}^{5}$ \\ ${ }^{15}$ Belgorod National Research University, Belgorod, Pobedy St. 85. 308015 Russia
}

\begin{abstract}
The relevance of the research corresponds to modern trends in the development of science and technology and is determined by social tasks in the meeting human needs in providing a comfortable environment within the common lands of specific localities. Man is a part of nature itself and his whole life is inextricably linked with nature. Man, and his work become an active principle that transforms nature. It is necessary to pay attention to the changes in the landscape, the violation of the integrity of natural complexes, and the environmental pollution. In addition, prevent the deterioration of the environmental situation, predetermined by the intensification of anthropogenic pressure on the environment. The article describes the approaches to the study of patterns of the social-geographical parameters of regional environmental management. The variant of the author's methodology for the study of social-geographical aspects of public nature management and assessment of aesthetic and consumer parameters of the environment is proposed and tested. The case study was conducted in the rural village Streletskoe, Krasnogvardeisky district of Belgorod region. Based on the results of the study, we obtained significant results of social-geographical parameters of regional environmental management. In conclusion the population of the Streletskoye rural settlement is definitely characterized by its own specific socio-geographical parameters of natural resource management. Thus, the results obtained can be used in the territorial scheme of nature protection, in the General plan of settlements, during the environmental assessment, and also in the future can serve as a basis for the implementation of landscape planning. Research materials can be used as local history material.
\end{abstract}

KEY W ORDS: ATTRACTIVENESS, ENVIRONMENT, IMPLEMENTATION, MANAGEMENT, RURAL TERRITORY, SUSTAINABLE DEVELOPMENT.

\section{INTRODUCTION}

In recent decades, there has been an increased interest in cultural landscapes, their historical, cultural, and social and geoecological study. Research on landscape aesthetics and natural resource management is becoming increasingly urgent (Borsuk, 2000; Likhacheva and Timofeev, 1978; Nazarov and Postnikov, 2002; Chervan et al., 2016; Carlson, 1994; Trikart, 1979). Any landscape has its own unique appearance, i.e., a scenery that acts as a carrier of information about the culture, traditions and customs of the people living there. In addition, landscapes are of interest both economically and in terms of influence on people, their psychophysiology and health, beautiful sceneries help to create a locality trademark - for tourist business (Nikolaev, 1999; Nikolaev, 2002; Rodoman, 1995;

Article Information:*Corresponding Author: lopina@bsu.edu.ru Received 18/07/2021 Accepted after revision 27/09/2021

Published: 30 $0^{\text {th }}$ September 2021 Pp- 1026-1032

This is an open access article under Creative Commons License,

Published by Society for Science \& Nature, Bhopal India.

Available at: https://bbrc.in/

Article DOI: http://dx.doi.org/10.21786/bbrc/14.3.19
Frolova, 1994; Eringis and Budryunas, 1971; Bunting and Gueelke, 1979; Downs and Meyer, 1978; Haeyrynen, 1996; Penning-Rowsell, 1974; Rushton, 1979; Lopina et al., 2018; Zelenskaya et al., 2019; Ivanov et al., 2020 Yee et al., 2021).

A human is a part of nature itself and his/her whole life is inextricably linked with the natural environment. A human and his/her work become an active initiator, which transforms nature, and therefore it is essential to pay attention to any landscape change, violation of natural complexes integrity and environmental pollution (Chervan et al., 2016; Lopina et al., 2018; Silchenko and Semeniuk, 2019; Yee et al., 2021). Finally, yet importantly, it is important to prevent any degradation of the ecological situation predetermined by intensified anthropogenic pressure on the environment. Thus, there is a long-felt need to improve and enrich the modern rural visual environment and enhance the aesthetic effect. The purpose of this study is to establish consistent 
patterns for socio-geographical parameters of regional natural resource management. The study was conducted in the Streletskoye Rural Settlement of the Krasnogvardeysky Municipal District of the Belgorod Region.

\section{MATERIAL AND METHODS}

Taking into account the currently available theoretical and methodological developments by domestic and foreign scientists, the proprietary methodology titled "Study of socio-geographical aspects of public natural resource management and assessment of aesthetic and consumer parameters of the environment" was developed (KireevaGenenko and Senkina, 2015; Kireeva-Genenko et al., 2013; Lopina et al., 2015; Lopina et al., 2017; Lopina et al., 2018). The procedural framework of the study was supplemented by traditional geographical research methods: sociological, comparative geographical, cartographic, mathematical and statistical ones.

The Belgorod region is a region of intensive economic development, in which environmental problems have accumulated in the use of land, water, forest, recreational and other resources (Zinchenkou et al., 2013; Lisetskii et al., 2014; Zelenskaya et al., 2019; Ivanov et al., 2020). The findings of the studies conducted by the authors during 20152019 (questionnaire results) as well as periodicals, library and archive funds of the Administration of the Streletskoye Rural Settlement in the Krasnogvardeysky District of the Belgorod Region were used as source material.

\section{RESULTS AND DISCUSSION}

The proposed version of the methodology to be used to study socio-geographical aspects of natural resource management, consistent patterns of socio-geographical parameters, and estimated aesthetic and consumer parameters of regional natural resource management includes the following stages and their content: 1 . Preparatory stage:- Justification of the relevance and objectives of the study.- Justification of evaluation methods.2. Organizational stage:-Development of routes with relevant number of settlements of different types in all districts of the Belgorod Region.- Representative sample calculation for a locality.3. Evaluation stage:Development of personal questionnaire.- Selection of respondents based on two indicators: by age group and by the length of residence in the study area. - Conducting a socio-geographical survey (questionnaire) in the selected localities. 4. Synthesis stage:-Summarizing the results into a consolidated table in Microsoft Excel format.-Analysis of field research results.5. Design stage:- Scheme development for a visual representation of results.- Design of visual materials - development of maps. 6. Final stage.

The territory of the Krasnogvardeysky District where the Streletskoye Rural Settlement is located is in the southern part of the Central Russian Upland, in the eastern part of the Belgorod Region. The Krasnogvardeyskoye Settlement, which is the centre of the district, is located at $38^{\circ} 24$ east longitude and at $50^{\circ} 39^{\prime}$ north latitude, 145 $\mathrm{km}$ west of Belgorod, and the regional centre. The area of the Krasnogvardeysky District is 1,762.6 km2 (17,6263 ha), the area of Krasnogvardeyskoye district centre is $13.7 \mathrm{~km} 2(1,371 \mathrm{ha})$ within the settlement limits. On the territory of the district, there are 86 settlements with an area of 13,481 hectares $(7.6 \%$ of the district's area); they are under the jurisdiction of 14 rural and one-settlement administrations.

The industrial land in the district occupies a total area of 918 hectares $(0.5 \%$ of the district's area) and Valuyskaya Maintenance Section No. 11 of the South-Eastern Railway, Department of Public Roads, RAO United Energy System of Russia, the Belgorodenergo Eastern Electric Networks and the Mostransgaz Main Gas Pipeline, represents it. In addition, it includes 12 gas stations and oil depots of Belgorodnefteprodukt JSC. The main direction of the district's economy is agriculture. The agricultural lands occupy $132,759 \mathrm{ha}$, including arable land $-70.6 \%$, gardens $-1.1 \%$, and hayfields $-4.3 \%$ and pastures $-24.0 \%$.

The district's terrain relief is primarily characterized by its location on the south-eastern spurs of the Central Russian Upland. It occupies a watershed plateau between the basins of the Oskol River and the Tikhaya Sosna River, both flowing into the Don. The entire territory is largely dissected by the well-developed gully-ravine system. There are individual elevated or lowered places as clearly contrasted with the even land. The most elevated part is located on the lands belonged to Bolshebykovo and Verkhososna villages, it rises up to 200-220 m above sea level while the lowest part is the floodplain of the Palatovka River. The watershed slopes are subject to erosion processes, they can reach up to $2-4 \mathrm{~km}$ in length, and the ravines can sometimes extend up to several tens of kilometres. In the district, there are quite a lot of gullies, i.e., deep depressions with steep exposed slopes and a narrow bottom. The glaciation of the Russian Plain, which started in the Quaternary period, affected the Don River valley with its eastern wing. The deposits made on the territory of the district during this period are represented by significant reserves of various clays and sand (Lopina et al., 2015; Zelenskaya et al., 2019)

There are pottery clays near the villages of Sadki and Nikolskoye, and approximately Palatovo, Livenka and Filkino, there are reserves of refractory and highmelting clays. Local clays are used to make bricks. In the quarries located approximately the villages of Gorovoye, Chermenevka and Malobykovo, near the Biryuch railway station, and in some other places sand mining is underway for the needs of the district. The climate of the region is specifically characterized by the influence from the Asian continent during spring and summer periods, from there some continental hot air masses, i.e., dry winds, tend to come, thus causing atmospheric and often soil drought. Drought events occur every 3-4 years. In the district, the average monthly temperature varies from $+20 \mathrm{oC}$ to $+22 \mathrm{oC}$ in summer (July) and between 8 and $9 \mathrm{oC}$ in winter (January). The duration of the warm period is 230-240 days, and that of the cold period is 120-130 days. The amount of precipitation is insignificant -450 to $470 \mathrm{~mm}$ per year. This is slightly less than the average number for the region. The river network of the district is sparse. All rivers run into the basin of the Sea of Azov (Lopina et al., 2017) 
The district is latitudinal dissected by the largest river, i.e., the Tikhaya Sosna. The total length of this river in the district is $43.5 \mathrm{~km}$. The following left-bank tributaries of the Tikhaya Sosna flow in the meridian direction: the Userdets $(26 \mathrm{~km})$ and the Sukhaya Sosna as well as the Valuy $(28 \mathrm{~km}$ within the district) with tributaries Palatovka $(19 \mathrm{~km})$ and Sennaya. All of them are low water. There are nine other small rivers and seventeen streams, sometimes unnamed, on the district's territory. Most of them dry up in summer time. The different-depth underground waters are not yet fully understood. Swamps occupy 380 hectares. The water bodies of the district cover only 1,222 ha or $(0.6 \%)$ of the total area. The Tikhaya Sosna and the Userd are the major rivers. There are ponds on rivers Renevod, Palatovod, Valuy, Sennaya and Userd. The ponds are mainly used for commercial fishing and irrigation (Lopina et al., 2018; Ivanov et al., 2020; Butkaliuk et al., 2021).

The main pollution sources for the district's rivers are as follows:

- The Tikhaya Sosna (it is polluted by rain-storm runoff from the settlement, enterprises and organizations as well as by poorly treated wastewater from the settlement's sewage facilities).

- The Userd (it is considerably subject to contaminations from the Krasnogvardeysky Fish Farm and it is polluted by manure-containing storm drains from the livestock farms).

- The Valuy (it is polluted by rain-storm runoff from Mashinostroitel OJSC and the Nikitovsky Fish Farm).

The ecological condition of surface waters in the water protection zones of the Tikhaya Sosna, Userd and Palatovka rivers is affected by violations of their use conditions by Pokrovka, Zasosenskaya, Streletskaya and Krasnogvardeyskaya settlement administrations. These are territories where there are cases of land plot ploughing in the water protection zones of the above-mentioned rivers. The Krasnogvardeysky District is rich in springs. There are more than 120 springs there, 55 of them are provided with proper infrastructure. It is planned to develop the springs located on the bank of the River Sosna in the village of Veseloye near the Belgorod - Rossoshch highway. The well-developed springs are all operational and they are maintained in a good sanitary condition. The coverage of centralized water supply in the district is $58 \%$. There are 61 wells to supply water to the population of the district. The total length of water supply networks is more than $200 \mathrm{~km}$. There are operational treatment facilities for household and industrial effluents located in the settlement of Krasnogvardeyskoye and the village of Livenka respectively, the treated wastewater is discharged into the Tikhaya Sosna River and the Valuy River (Lopina et al., 2018; Ivanov et al., 2020; Yee et al., 2021).

In the settlement of Krasnogvardeyskoye and the village of Livenka the treatment facilities have been long used without any necessary major repair, wastewater fails to be automatically chlorinated. Maximum permissible discharge limits (MPL) for treated wastewater have been neither developed nor agreed upon. Due to the fact that the industrial effluents produced by both the
Krasnogvardeysky Milk Factory and the canning factory of Domat LLC have considerably higher MAC (maximum allowable concentration) because of non-compliance with wastewater collection regulations, the treatment facilities located in the Krasnogvardeyskoye settlement discharge post-treatment substandard effluents into the Tikhaya Sosna River. The prevailing type of soils in the district are typical and ordinary Chernozem, which occupy $34 \%$ of the total cultivated area. The thickness of the humus layer reaches 60 to $70 \mathrm{~cm}$ in some places. They are most widespread in the northern half of the district (Geography, 2001).

Grey forest soils rank second after Chernozem. They are mostly occupied by woodlands. The thickness of the humus horizon is slightly higher than in chernozems. Their fertility is somewhat lower. There are narrow strips of meadow alluvial (riverside) and Chernozem meadow soils usually going along the floodplains. They occupy a little more than $8 \%$ of the total area of the district. On the floodplains of the Tikhaya Sosna and the Userdets rivers, there are swampy areas where meadow and floodplain soils with high organic matter content are formed. Near the villages of Maloalekseyevka, Kazatskoye, and Ezdotskoye and in some other places, there are sphagnum swamps where it is possible to extract peat for fertilizers. There are sparse spots of alkaline soils and exposed cretaceous (carbonate) outcrops.

The structure of the land fund of the district is as follows: lands intended for agriculture $-66.7 \%$, areas covered by inhabited localities $-7.7 \%$, industrial and transport lands $-0.5 \%$, forest resources $-12.6 \%$ and free available land $-12.5 \%$. The district's land is mainly characterized by the maximum degree of development of erosion processes. The territory of the district is located on slopes with various steepness, more gentle slopes of up to $8^{\circ}$ are used for arable land, and pastures are on slopes of up to $20^{\circ}$. A significant area (more than 3,000 hectares) is occupied by gullies. The rugged topography and the transfer of arable farming systems from plains to slopes have led to the fact that nowadays $73 \%$ of the district's land is erosion-prone and erosion threatening and part of the land is withdrawn from agricultural use (Geography, 2001; Buryak and Marinina, 2020; Butkaliuk et al., 2021).

Because of the intensive use of arable land in the district, there are no Chernozem left with a very high content of humus, and those with high and increased humus content make up only $21.9 \%$. Most of the land (77.8\%) has a medium and low humus content. In the last 20 years, up to $20 \mathrm{~cm}$ of the humus horizon have been washed away. Nutrients are also washed out of the soil proportionally, which affects the agricultural yield. The Krasnogvardeysky District is geographically located at the junction of two natural areas: steppe and forest-steppe. Forests cover 24,245 hectares, which is $14 \%$ of the total area of the district. There are no purely oak forests. Usually, it is a three-tiered forest canopy consisting of various tree species. The first tier is occupied by oak and common ash, in some places - aspen. Below there are fruit, elm, and maple trees. One can sporadically see rowan tree, bird cherry, linden, and willow. In the third tier, there are shrubs: hazel, hawthorn, 
blackthorn, rough spindle tree, rosehip and others. There are alders and thick willow along the floodplains and swampy areas. It is typical for the forb-feather grass steppe to have herbaceous vegetation.

The original steppe space is mostly ploughed. The herbage is lower and sparser there. It is predominated by xerophilous cereals with a deep root system. On the bottom deposits, the herbage is slightly higher. There you can find foxtail, meadow fescue, grasshopper, and others. There are thyme or meadow thyme, chalky hyssop growing on the blackened cretaceous outcrops. There are cloven-hoofed animals such as elk, roe deer, and wild boars all over the forests of the district. Among the mammals, rodents are widely spread. One can also see a brown hair. A wolf represents predators. A red fox is of great value as a commercial animal. There are several species of martens. There are about 250 species of birds. One can see herons, wild geese, and sometimes cranes and storks. Some rare and endangered plants can be found on the territories of botanical reserves: Kozopolyansky rock jasmine, low iris, large-flowered hedysarum, bulbocodium, pasqueflower, Biberstein tulip, May lily of the valley, Russian fritillary, sandy caraway, wood anemone, and others (Lisetskii et al., 2014; Yee et al., 2021)

Currently there are two species reserves in the district:1) The Pokrovsky Nature Reserve with a total area of 15,000 hectares was formed in order to preserve the populations of elk and deer;2) The Mandrovsky Nature Reserve with an area of 25,000 hectares, aimed at the conservation of such species as elk and European deer (according to the data recorded in 2017 there are 7 elks in the reserve). There are no breeding stations in the district. Currently, the natural water reservoirs of the district are inhabited by about 12 fish species, 6 of them are commercial ones. Because of changing conditions, the number of many fish species in the water reservoirs of the district has decreased. This is primarily due to pollution and destruction of their habitat. It is allowed to plough water conservation zones and coastal strips. The district has some historical and cultural landscape components. In the village of Nikitovka, the Krasnogvardeysky District, there is "Life-Giving Spring" - a spring consecrated in honour of the icon of the Most Holy Theotokos. In the centre of the city of Biryuch, there is a building of the former district council. Its history and unique style make it an attractive venue for various events. Various regional cultural programs are organized there: anniversaries are celebrated, meetings with writers, notable countrymen and district guests are held. The district council building is a tourist attraction of the Krasnogvardeysky District (Hryniuk and Hryniuk, 2020; Butkaliuk et al., 2021)

The Epiphany Spring that is located in one of the picturesque places of the village of Veseloye has recently become the place of recreation for the residents of the village and the Krasnogvardeysky District. The spring carries latent inexhaustible energy and mysterious depth. The life-giving spring is surrounded by many secrets and legends. The spring water has the same temperature, + $8 \mathrm{oC}$, in winter and summer; the water of this spring is valued for its healing and taste qualities. The holy spring of St. Nicholas the Wonderworker on the Userdets River is located in the northwestern part of the village of Sorokino. The spring flow is constant. The water in the spring is colourless, transparent, odourless, and has a pleasant taste. The temperature of the spring is constant, $50 \mathrm{C}$. In winter, the water in the spring does not freeze. The Krasnogvardeysky District is characterized by high rates of territory settlement and development (Lisetskii et al., 2014, Silchenko and Semeniuk, 2019, Butkaliuk et al., 2021).

The high attractiveness of the territory is primarily due to the favourable natural conditions for living and farming. The study was conducted in the Streletskoye rural settlement, which is located in the eastern part of the Krasnogvardeysky District and was established on December 20, 2004 in accordance with the Law of the Belgorod Region No. 159. The administrative centre of the rural settlement is the village of Streletskoye, which is located on the hill at the confluence of the Userdets and Tikhaya Sosna rivers in the forest-steppe zone in the southeastern part of the Belgorod Region, $158 \mathrm{~km}$ away from the city of Belgorod. The rural settlement includes the village of Kazatsko, the village of Maloalekseyevka, the village of Malobykovo, the village of Streletskoye that is an administrative centre, and the hamlet of Yampi.

The total population of the Streletskoye rural settlement is 2,642 people as of January 01,2020 . The settlement's economy relies on agricultural production. There are deposits of sand, white and red (red - pottery) clay and chalk on the lands of this area. The social and cultural sector of the Streletskoye rural settlement includes the following community centres: Kazatsky, Malobykovsky, Streletsky. The educational sector of the settlement includes three secondary schools and three kindergartens located in the villages of Streletskoye, Malobykovo and Kazatskoye. The main rural sightseeing places, which predetermine the development of rural tourism, include the following: - A collective grave of 36 Soviet soldiers who died in the battles against Fascist invaders in 1943 (the village of Streletskoye).

- An ensemble of the 19th century: The Church of Our Savior with the interior dated back to 1845 , the house of clergy (the second half of the 19th century), a fence with a gate (the second half of the 19th century) (the village of Streletskoye).- On the left bank of the Tikhaya Sosna River, there are some remains of the ancient settlement of Kamenny Brod (the village of Streletskoye) preserved.- Liman isolated terrain feature (near the village of Malobykovo) - a nature reserve for conservation of rare plant species.Religious sites: The Church of the Demetrius of Thessalonica, the Great Martyr (the village of Kazatskoye), the Church of Our Savior (the village of Streletskoye), the Church of St. Sergius of Radonezh (the village of Malobykovo).

As part of the study of socio-geographical parameters of regional natural resource management, in addition to the development of brand identity for the district and thus the rural territory, we conducted a sociological survey (questionnaire survey) in which 813 respondents took 
part (the confidence probability was $0.683 \%$ ). The analysis results for the spatial and temporal characteristics of the natural resource management areas are presented below: - most frequently visited territories: the average distance varies from 0.3 to $0.7 \mathrm{~km}$; the average range radius is 0.5 $\mathrm{km}$; the average frequency of visits is 3 times per week;frequently visited territories: the average distance varies from 0.8 to $2.0 \mathrm{~km}$; the average range radius is $1.4 \mathrm{~km}$; the average frequency of visits is 2 times per week;- rarely visited territories: the average distance varies from 2.0 to $15 \mathrm{~km}$; the average range radius is $8.5 \mathrm{~km}$; the average frequency of visits is one time or less per week. The number of going-outs by local residents for the purpose of "pure recreation" is $28 \%$, the remaining number of respondents $(72 \%)$ prefer to combine recreation with other types of natural resource management.

Figure 1: Attendance of the territories of the Streletsky rural settlement

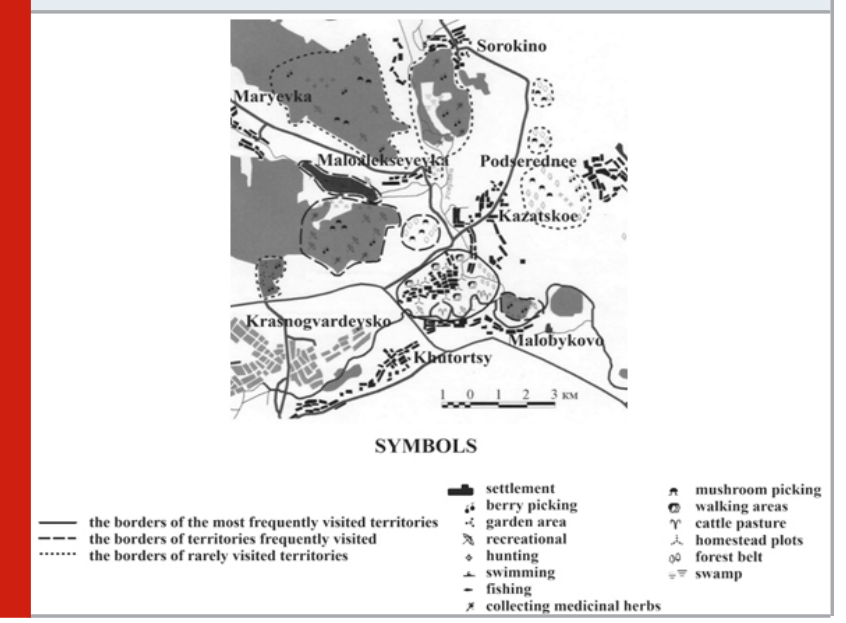

Figure 2: Types of public nature management used by residents The Streltsy of the rural settlement of Krasnogvardeysky district

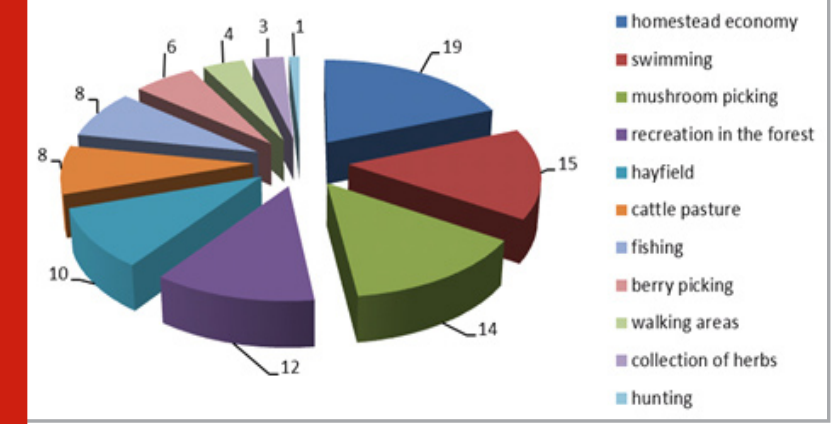

The frequency of population-nature contacts in spring and summer varies from daily visits to the surrounding nature to one time a week per person near the settlement in autumn and winter. The frequency of visits by local residents to natural and cultural sites is decreasing as they move away from their place of residence. Most local people go more frequently outside the rural territory in summer; the population leaves the territory of the settlement because they need to visit the regional centre. This is mainly the city of Belgorod and the surrounding area. Using the obtained data, we compiled a sketch map titled "Attendance of the Streletskoye Rural Settlement Sites" (Fig. 1) with highlighted areas: the most frequently, frequently and rarely visited territories as well as the prevalence of different types of public natural resource management among the respondents. The sketch map clearly shows the most valuable territories for the residents of the Streletskoye rural settlement, which have a great recreational and consumer appeal. The closest area is most frequently visited (the average distance is $0.5 \mathrm{~km}$ ). It is characterized by the greatest variety of types of natural resource management. The people living in the Streletskoye rural settlement actively visit the centre of their residential place. On holidays and weekends, they prefer to go to the administrative centre of the rural settlement.

In rarely visited natural landscapes, which are located at a distance of 0.8 to $2 \mathrm{~km}$, there is nothing to do but have a rest in the forest, near water and sometimes hunting. Going farther away from the settlement there are some "detached areas" with their landscapes being used rarely. Moreover, an analysis of the questionnaire data made it possible for us to identify the dominant types of natural resource management.

The landscapes of the Streletskoye rural settlement have changed significantly and they are not dissimilar to the urban ones. This point can be noted not only by visiting the rural settlement but also by analysing the responses of the local residents. However, one particular feature should be noted: as a rule, respondents are satisfied with what they observe in the environment of their place of residence. They do not want to contemplate wild landscape pictures, which are as close as possible to natural ones. They prefer cultural, well-developed landscapes (gardens, parks, miniparks). More than $70 \%$ of the respondents have contacts with nature 6-8 times a year. Nature is the main place for diverse recreation. The study materials can be used as local natural history material, as well as in the formation of students' environmentally oriented approach to their future professional activities (Lisetskii et al., 2015; Kudryavtseva et al., 2020; Butkaliuk et al., 2021).

\section{CONCLUSION}

Thus, the inhabitants of the Streletskoye rural settlement are certainly characterized by their own specifics in the aesthetic perception of landscapes. However, even among the local residents, there are significant differences in perception particular features, which is associated with a number of reasons. The main reason is the origin and duration of residence of respondents in the study area since the aesthetic appearance of the native landscape which is established in childhood and adolescence during the period of long-term residence in this territory forms the psychological self-identification of the respondent with these landscapes, which makes it possible to state that they are of great value. We visually examined the sites of natural resource management in general and recreation in particular which the residents of the Streletskoye rural settlement prefer. Based on the survey we have proposed some recommendations to improve recreational conditions 
within the rural settlement, for example: to improve the territory adjacent to the Monastyrsky Spring (the village of Streletskoye).

For this purpose, you can install a pergola near the spring so that people could have an opportunity to relax after a long road to the spring; you can set up some recreation grounds in forest areas and improve places for recreation and safe bathing on the rivers Userdets and Tikhaya Sosna. Thus, we can draw the following conclusions: the population of the Streletskoye rural settlement is definitely characterized by its own specific socio-geographical parameters of natural resource management. The obtained significant results can be used in the territorial nature protection scheme, in settlements master plan and environmental impact assessment; in the future, they can also serve as a basis for the implementation of landscape planning activities.

\section{ACIKNOWLED GEMENTS}

The study was carried out within the framework of the intrauniversity grant of the Belgorod State University to support the creation and development of scientific departments centers of excellence.

\section{REFERENCES}

Borsuk, O.A. and Timofeev, D.A. (2000). Relief as a natural and cultural heritage. Pp. 14-15. Problems of Ecological Geomorphology Proceedings of the Interstate Meeting of the XXV Plenum of the Geomorphological Commission of the Russian Academy of Sciences. Belgorod, Russia.

Butkaliuk, K., Shchabelska, V., Bykova, M. and Pologovska, I., (2021). Socio-Geographical Concept of Labor Market Monitoring and Regional Employment Policy Formation. In SHS Web of Conferences (Vol. 100). EDP Sciences.

Bunting, T.E. and Gueelke, L. (1979). Behavioral and perception geography: A critical appraisal. Annals of the Association of American Geographers. Vol 69(3) pp 448-462.

Buryak, Z. and Marinina, O. (2020). Using GIS technology for identification of agricultural land with an increased risk of erosion. E3S Web of Conferences, 176, 04007, https://doi.org/10.1051/e3sconf/202017604007

Carlson, A. (1994). Appreciation and the natural environment. Environmental ethics, ed. Lonis P. Pojman, Boston-London, Jones and Bartlett Publishers. . pp 142147

Chervan, A.N., Romanova, T.A., Lisetskiy, F.N. and Narozhnyaya, A.G. (2016). Geosystem approach to the organization of nature management in waterlogged agricultural landscapes (on the example of the agricultural and industrial complex "Lovzhansky" in the Vitebsk region of Belarus). Nauch. Ved. Belgorod. Gos. Univ., Ser. Estestv. Nauki. Vol 37 (25) pp 143-155. Downs, R.M. and Meyer, J.T. (1978). Geography and the Mind: An Exploration of Perceptual Geography. American Behavioral Scientist. Vol 22(1) pp 59-77.
Eringis, K.I. and Budryunas, A.R (1971). Vegetation and landscape aesthetics. Issues of protection of botanical objects. Nauka, pp 84-92.

Frolova, M.Yu. (1994). Assessment of the aesthetic merits of natural landscapes. Vestnik - Moskovskogo Universiteta, Seriya Geografiya. 24 pp 27-33.

Geography of the Belgorod region (2001). Part I. Nature. (Edited by) Vasilenko, M.V., Chendev, Yu.G. Moskow: Sport Akadem Press 120.

Haeyrynen, M. (1996). National landscape imagery in the making of Finland. New Comparison. No.21 Pages 146-162.

Hryniuk, D.Y. and Hryniuk, T.A., (2020). Economic and geographical aspects of the study of the competitiveness of the reqion. Publishing House "Baltija Publishing". Ivanov, A.L., Savin, I.Y., Stolbovoy, V.S., Shishkonakova, E.A. and Kashtanov, A.N. (2020). Map of anthropogenic soil erosion of Russia. Doklady Earth Sciences. 493(2) Pages 654-657. DOI: 10.1134/S1028334X20080097.

Kudryavtseva, T., Skhvediani, A. and Berawi, M.A., 2020. Modeling cluster development using programming methods: Case of Russian arctic regions. Entrepreneurship and Sustainability Issues, 8(1), p.150.

Kireeva-Genenko, I.A. and Senkina, A.A. (2015). Intermediate results of the study of public nature management on the example of the Korochansk district of the Belgorod region Scientific view of modern society: a collection of articles Intern. scientific-practical conf., Ufa. Rio MTsia Omega Since pp 131-132.

Kireeva-Genenko, I.A., Lopina, E.M., Belousova, L.I., Bochkovskaya, A.G. and Petina V.I. (2013). Sociogeographical aspects of studying the public nature management of rural settlements of the Belgorod region (on the example of the Central rural settlement of the Rakityanskiy district). 5. [Electronic resource]. - URL: http://www.science-education.ru/111-10462.

Likhacheva. E.A. and Timofeev, D.A. (2002). Relief of the human environment (ecological geomorphology). Manmade landscapes (Edited by) F.N. Milkov - MoskowMysl. 640.

Linton, D.L. (1968). The Assesment of Scenery as a Natural Resource. Scotish Geographical Magazine. Vol 84 pp 219-238.

Lopina E., Kornilov, A., Bondareva, Y. and Kalugin V. (2018). Factor Assessment of the Aesthetic and Consumer Parameters of Regions. The Journal of Social Sciences Research. 77-81. URL: 10.32861 / jssr.spi1.77.81 https:// www.arpgweb.com/pdf-files/SPI-1-JSSR18-48-77-81. pdf.

Lopina, E.M., Kornilov, A.G., Petin, A.N. and KireevaGenenko, I.A (2017). Assessment of consumer and aesthetic parameters of the environment at the regional level. International Business Management, Vol 10(16) pp 3364-3368.

Lopina, E., Kornilov, A. and Prokudina, V. (2015). Bewertung von Freizeitbelastung in Bereichen der 
Unterkunft von Bergbauwerken der KMA. International University of Resources Scientific Reports on Resource Issues 2015 Volume 1 Innovations in Mineral Ressource Value Chains Geology, Mining, Processing, Economics, Safety, and Environmental Management Supported by the IUR Partner Universities Scientific Reports on Resource Issues.

Lisetskii, F.N., Pavlyuk, Ya.V., Kirilenko, Zh.A. and Pichura, V.I. (2014). Basin organization of nature management for solving hydroecological problems. Russian Meteorology and Hydrology. Vol 39(8) pp 550-557.

Lisetskii, F., Terekhin, E., Marinina, 0. and Zemlyakova, A. (2015). Integration strategies of academic research and environmental education. Procedia - Social and Behavioral Sciences. Vol 214 pp 183-191.

Nazarov, N.N. and Postnikov, D.A. (2002). Assessment of the landscape-aesthetic attractiveness of the landscapes of the Perm region for tourism and recreation. Vol 134(4) pp 61-67.

Nikolaev, V.A. (1999). Aesthetic perception of the landscape. Vestnik - Moskovskogo Universiteta, Seriya Geografiya. Vol 6 pp 10-15.

Nikolaev, V.A. (1999). The phenomenon of landscape. Vestnik - Moskovskogo Universiteta, Seriya Geografiya. Vol 6 pp 12-19.

Penning-Rowsell, E.S. (1974). Landscape Evolution for Development Plans. Journal of the Royal Town Planing
Institute. Vol 60 pp 930-934.

Rodoman, B.B. (1995). Landscape Aesthetics. Science of Culture: Results and Prospects. Information and analytical collection. Vol 3 pp 4-19.

Rushton, G. (1979). On behavioral and perception geography. Annals, Association of American Geographers. Vol 69 pp 463-464.

Silchenko, Y.Y. and Semeniuk, L.L., 2019. Tendencies of development and territorial features of the Kirovograd region labor market. (10), pp.61-66.

Trikart, J. (1979). Paysage et ecologie. Revue de geomorphologie Dynamique. 3 pp 30-34.

Yee, J.Y., Loc, H.H., Le Poh, Y., Vo-Thanh, T. and Park, E., (2021). Socio-geographical evaluation of ecosystem services in an ecotourism destination: PGIS application in Tram Chim National Park, Vietnam. Journal of Environmental Management, 291, p.112656.

Zelenskaya, E.Ya., Kukharuk, S.A., Naroznyaya, A.G., Martsinevskaya, L.V. and Sazonova, N.V. (2019). Bioecological assessment of arable soil pollution: a case study of Belgorod Region. Biosci. Biotech. Res. Comm. Vol 12(3) Pages 548-555.

Zinchenkou, V.E., Lokhmanova, O.I., Kalinichenko, V.P., Glukhov, A.I., Povkh, V.I., Shljakhova, L.A. (2013). Space monitoring of agricultural lands in southern Russia. Izvestiya Atmospheric and Oceanic Physics. Vol 49(9) pp 1036-1046. 